\title{
Health Belief Model on Psychosocial Factors Influencing HIV/AIDS Prevention Behavior on Lesbian Community in Surakarta
}

\author{
Maria Paula Marla Nahak¹), Argyo Demartoto²), Bhisma Murti1) \\ 1)Masters Program in Public Health, Sebelas Maret University, Surakarta \\ ${ }^{2)}$ Faculty of Social and Political Sciences, Sebelas Maret University, Surakarta
}

\begin{abstract}
Background: HIV/AIDS keeps on becoming a global problem. Even though there are some scientific breakthroughs on the disease and how to prevent, most people are still under the risk to contract it. The number of HIV/AIDS incidences on lesbian is still low, up to the point of considering them as low risk. This study aimed to analyze Health Belief Model on the psychosocial factors that influence HIV/AIDS prevention behavior in lesbian community in Surakarta.

Subjects and Method: This was an analytic qualitative study with phenomenology approach, conducted at Talita Kum Community, Surakarta. Key informant in this study was the Head of Talita Kum Community, with their members as main informants, and supporting informants from the health workers, Non-Government Organization and Regional Commission on AIDS Prevention (KPAD), selected by purposive and snowball sampling. The data were collected by in-depth interview, non-participating observation, and document review. The data were analyzed by Miles and Huberman method.

Results: The lesbian community in Surakarta is quite knowledgeable on the HIV/AIDS concept. But they still did not have enough understanding of how to prevent it. This could be very beneficial to lessen the chance of HIV from spreading and evolving into AIDS. The study result stated that the lesbian community did not consider themselves to be on the risk. Therefore, they lack the preventing method. However, bisexual woman considered herself to be at high risk; therefore, she regularly conducted medical check-up.

Conclusion: The knowledge of HIV/AIDS risk factors on lesbian have to be socialized so they could take the proper prevention steps.
\end{abstract}

Keywords: lesbian, health belief model, psychosocial factor

\section{Correspondence:}

Maria Paula Marla Nahak. Masters Program in Public Health, Sebelas Maret University, Surakarta. Email: marlanahak858@gmail.com. Mobile:+6282328282282.

\section{BACKGROUND}

HIV/AIDS keeps on becoming a global problem. Even though there are some scientific breakthroughs on the disease and how to prevent, most people are still under the risk to contract it. Based on the report by WHO (2016), in 2015 there were about 36.7 (34.0-39.8) million people who were infected by HIV from all over the world, which $2.1(1.8-2.4)$ million of them are newly infected. In the same year, there were 1.1 million people died of HIV/AIDS. Most of them lived in low and middle income countries. Moreover, UNAIDS (2016) stated that up to this day, only $54 \%$ of people with HIV/AIDS who are fully aware of their status. This epidemic does not just affect the individual but also could affect household and society growth, as well as impacting the country's development and growth.

In Indonesia, HIV/AIDS was first discovered in the province of Bali in 1987. Nowadays, HIV/AIDS has spread to all cities in Indonesia. Indonesian government 
Journal of Health Promotion and Behavior (2017), 2(1):15-26

https://doi.org/10.26911/thejhpb.2017.02.01.02

through the Ministry of health have collaborated with various organizations both national and global ones as an effort to prevent HIV/AIDS, but the toll of people infected as well as death due to HIV/AIDS are still on the rise. Since 1987 until September 2014, there are 150,296 people with HIV Indonesia, and there are 55,799 people with AIDS. Based on the risk factors, the cumulative number of HIV/AIDS on 2014 were as followed: heterosexual were 34,305 cases; homo-bisexual were 1,366 cases, IDU were 8,462 cases, blood-transfusion were 130 cases, pre-natal transmission 1,506 cases and unknown in 9,536 cases (Kemenkes RI, 2014).

In Surakarta, the number of HIV/ AIDS is spiking high and it gets worrisome. This is apparent from the toll of HIV/AIDS patient that steadily rising every year. Commission of AIDS Prevention of Central Java Province (2015) reported that there are 738 cumulative cases of HIV and AIDS in Surakarta during the period of 1993-September 30,2015 , which this is the second highest number in Central Java. Commission of AIDS Prevention of Surakarta stated that during the period of 2005-October 2016, they recorded a total of 2,068 cases of HIV/ AIDS in Surakarta.

Why are lesbians considered high risk for STI and HIV/AIDS? Generally, the number of HIV/AIDS reported to occur in a lesbian community is quite low. In fact, many people considered that lesbian or woman who has sex with a woman (WSW) as low. These women did not seem to be at high risk to be infected with HIV. The lack of evidence is related to the lack of concern from organizations that categorized lesbian as a low-risk group. The lack of concern added to the myth of "lesbian immunity."

Sandfort et al. (2013) in their study in South Africa proved that there is Sexual Transmitted Infection (STI) in lesbian or
WSW. They found that the WSW has a higher chance of contracting Chlamydia Trachomatis in oppose to straight women. They also hold higher toll on HIV/AIDS than the heterosexual ones. Diaz et al. (2001) concluded similar result on their study. They stated that the number of HIV/AIDS on WSW tend to be higher than on heterosexual because WSW also involved in sexual activity with men. Moreover, the risk of being infected with HIV/AIDS in the lesbian community is related to using injected drug and sharing their sex toys.

Based on these ideas, we decided to take a further analysis in order to get more information about the factors that could affect the HIV/AIDS prevention behavior in lesbian community in Surakarta.

\section{SUBJECTS AND METHOD}

This was an analytical qualitative study with phenomenology approach, in order to dig up information on factors influencing HIV/AIDS prevention behavior in lesbian at Talita Kum community in Surakarta with Health Belief model analysis. This study was conducted in Surakarta during January to March 2017. The study was conducted in Surakarta after deliberating some factors, such as the rise of number of incidence of HIV/AIDS. Also, there was an organization that actively advocating either individual or community that identifies them as lesbian, that was Talita Kum.

The data were selected by purposive and snowball sampling. We selected the sample that considered as important and could give the right information. The key informant in this study was the head of Talita Kum; the main informants were the lesbian members of Talita Kum, and supporting informants from the Commission of AIDS Prevention of the city of Surakarta, Health Office of Surakarta, health workers in Manahan Community Health Center and 
SPEK-HAM Non-Government Organization.

The data collection was conducted by in-depth interview, non-participating observation and document review. The data instruments were interview guidelines, stationary, laptop, notebook, voice recorder and camera to record the process. The data were analyzed by qualitative data by Miles and Huberman (1994; Leech and Onwuegbuzie, 2007)

\section{RESULTS \\ In the in-depth interview, we identified the sexual behavior of each main informants, like the numbers, type of sexual activity, and their take on the sex toys that based on several researchers was the tool for the HIV/AIDS virus to spread. Identifying the number and type of sexual activity was an important part because they could influen- ce the variable and heighten the risk on being infected with HIV or other STI. More- over, the use of sex toy during their sexual relation could be the medium needed by the HIV virus and other STI like herpes simplex, syphilis and others (Mercer et al., 2007).}

In this study, almost all informants had a sexual partner with a sexual pattern that did not differ much between one another. The Lesbians activity were kissing, petting, necking, cunnilingus and fingering. One of the lesbian informants also stated that she did sex trade with one of her expartner who turned out to be a bisexual. The sexual acts mentioned by bisexual informant were kissing, petting, necking, fingering and sexual intercourse.

Some researchers have proven that using sex toy could spread HIV or other STI. This is due to a direct contact between sex toy and vagina or rectum (WSDH, 2014). Information from some main informants showed the variety of sexual pattern, but there was not any informants that used a sex toy in her sexual relation. Both lesbian and bisexual had never use any sex toy due to the lack of comfort.

\section{Knowledge and Attitude on HIV/- AIDS}

In this aspect, we identified the informant's understanding level on the general concept of HIV/AIDS that included the understanding, causes, clinical manifestation, prevention and source of information. This referred to the study by Hilgert et al. (2003) who state that there is an assocaiation between knowledge and attitude, which means that the more knowledgeable someone is the better they will behave. In this context, good knowledge on HIV was expected to be related to taking steps to prevent HIV/AIDS.

Based on this study, the informants were quite knowledgeable in terms of HIV/ AIDS. They knew some basic information on what it was. The source of the information was GAYa Mahardika as the quote by the head of Talita Kum as follows:

"For information acces on HIV/AIDS, we used to get assisted by GAYa Mahardika, but me, as the head of Talita Kum, I only provide them information about sexual identity" (Head of Talita Kum Community (KI), March 3rd, 2017).

Whereas, almost all informants stated their worry on the effect of contracting HIV /AIDS which would influence their lives. This concern mostly caused by the lack of activity after being infected. However, an opposite sentiment was stated by informant who identified herself as a bisexual. She did not feel any fear of HIV/ AIDS, and willing to take full responsibility in the case for the worst. Generally, all informants take HIV/ AIDS as something that will deter their productivity. But their understanding of the matter still did not push them to take 
Journal of Health Promotion and Behavior (2017), 2(1):15-26

https://doi.org/10.26911/thejhpb.2017.02.01.02

necessary precautions. All lesbian stated that they always took a bath before and after sexual relation. But they did not go to do a regularly medical check-up, which could help prevent themselves from contracting HIV/AIDS.

Health Belief Model Constructs analysis in relation to preventing HIV/AIDS in the lesbian community.

\section{a. Perceived Susceptibility.}

In this aspect, we identified informant's perception of the susceptibility on being on the risk of contracting HIV/AIDS. All lesbians had this idea that their community had zero potential to spread HIV. This idea was supported by the head of Public Health and Disease Control Office of Surakarta who stated that the risk in the lesbian group were less. But this was different on the bisexual informant, whereas she perceived herself as on high risk to be infected based on her current sexual activity.

"I am highly susceptible, I often did not use any protection. That is why I often do a pap smear, and also go to an Indonesian Red Cross to donate so I will know if there is something wrong. But I admit that I did not do much to prevent." (U4, February 19th, 2017).

"Theoretically there are some risks at lesbian women. We also know that HIV transmitted by body fluid such as blood exposure. But for lesbians I think it is not a big deal, I mean they are not vulnerable because lesbian did not do a heterosexual relationship" (Health Office Staff (P1), Februari 22nd, 2017).

The similar opinion stated by SPEK-HAM Non-Government Organozation staff. She had the same idea about how deep the risk of lesbian related to HIV/AIDS.

"Actually, everyone is vulnerable to HIV but based on the risk factors, I think lesbians are more safer than homo- sexual man, unless lesbians engage in heterosexual sex. (SPEK-HAM NonGovernment Organization staff, February 23rd, 2017).

\section{b. Perceived Severity}

In this aspect, we identified informant's perception on the severity if they did not properly prevent HIV/AIDS, whereas almost all informants realized the severity of what will happen if they did not do anything.

"Well, I might get an STD, especially when I am in a hurry to do a sexual intercourse, I did not think to wash myself or to take a bath, and I remember that I ever had vaginal discharge and it smelled bad, but I kept quiet about it" (U2, February 25th, 2017).

However informant (U4) stated that she was aware of the fact that she might be infected if she did not do any prevention, but she did not take it as a threat. This was because she was no longer considered HIV/ AIDS as a scary thing.

"Well, I can get infected. But HIV is not as scary as it used to be. I have some friends who are HIV positive and they are just doing fine. They are still active, aside of sometimes get sick" (U4, February 19th, 2017).

Informants assume that the severity of HIV depend on how they apply an appropriate prevention behavior. It is not only to prevent HIV infection but also to prevent the other sexually transmitted infections. This quote was supported by the key informant (Head of Talita Kum Community) as follows:

"If we talking about probability to get $H I V$, it is depend on sexual behavior but in term of sexual it is not so threatening unless they use injection drug. Well, I used to know there were some drugs users but it was not IDU" (Head of 
Talita Kum Community (KI), March 3rd, 2017).

\section{c. Perceived Threat}

In this aspect, we identified the threats that the informants recognized or feel if they could not do any prevention steps. Quote from one of the informants:

"I do not think so, because I always use hand sanitizer every time I have sex. Well, if I remember to, and also I have no friends who infected by HIV" (U1, February 24th, 2017).

On the other hand, informant (U2) stated that if someone did not do the necessary precautions than they put themselves on the risk for HIV/AIDS. However, personally, (U2) did not feel any threat in her sexual relation.

"There is a possibility. But I am not scared. Cause even though we do not know if our partner is clean or not, but there is a vetting process before sex" (U2, February 25th, 2017).

Both lesbian and bisexual informants did not take HIV/AIDS as a threat. Bisexual informant considered herself to be ready for the worst outcome due to her lack of preventions.

\section{d. Perceived Benefit}

We identified the informants's perception on the benefits they feel from taking necessary precautions in their sexual relations. A quote from one of interviews:

"It must be very useful but it is not just about me being "safe", but also about her comfort. If it is me, keeping my vagina clean is my main priority" ( $\mathrm{U} 1$, February 24th, 2017).

"There are lots of benefits, and thankfully both pap smear and blood test turned out to be negative. So I am... good" (U4, February 19th, 2017).

Perceived benefit that we aim is the benefit that all informants could feel to prevent
HIV/AIDS. The more benefits they feel, the bigger chance for the individual to adopt a healthier lifestyle. Prevention steps were including shower before and after sexual relation and using antiseptic. Lesbians and bisexual informants thought that keeping their vagina and overall body clean are very beneficial. Aside for her own safety, her partner would also feel comfortable. they also thought that keeping her body clean would be enough to prevent various STI. In term of a clinical check-up, the lesbian involved in this study did not do it regularly. While the bisexual informant perceived the benefit of Pap Smear and she regularly does that on yearly basis.

\section{e. Perceived Barrier}

All informants stated that they did not face any obstacle on taking the prevention steps in their sexual relation. However, the barrier came in term of clinical check-up due to pap smear procedure and health administrator that lack of professionalism. And this resulted in their lack of interest to regularly checked themselves.

"The problem (arrises) when being in a hurry, and I am just lazy to do a pap smear. But I hate doing VCT cause I do not want to meet the administrator who tends to breach personal bubble" (U4, February 19th, 2017).

There is also an inflated trust on being "zero risks", causing the informants, especially lesbian ones, to not do the routine check-up.

"In term of problem, I never do a real check-up, because I never think that far. I tend to think I am free from any disease" (U2, February 25th, 2017).

\section{f. Cues to Action}

Cues to action referred to the clue or any role model for the informants. All of them were committed to being healthy and admitting that the drive came from their 
Journal of Health Promotion and Behavior (2017), 2(1):15-26

https://doi.org/10.26911/thejhpb.2017.02.01.02

friends and themselves, which is the drive to stay healthy and productive.

"What drives me to take precaution is myself, because I do not want to get sick" (U3, February 3rd, 2017).

"(My friends were) my drive. When I first took VCT, it was my friends who supported me. Because they all are sexual active with their own partners, so we took VCT together. As for pap smear, it was me. Sides, I already know the safe passages, so I am doing it regularly"(U4, February 19th, 2017).

\section{g. Self-Efficacy}

There was a varied degree of self-efficacy shown by the informants. Most of them were still trying to keep motivate themselves to take preventions in all their sexual relations.

"I am quite sure. I am still trying to. Well, I must be able to do it" (U3, February 7 th, 2017).

"I believe I could do better than now. I mean, sometimes it's hard for me to decline, especially with the guy" (U4, February 7th, 2017).

\section{DISCUSSION}

Lesbian is the label for an individual who have a strong attraction, whether physical, sexual and emotional, to another female (Doty et al. 2010). This term had strengthened the ignorance on the health status of this group. As a minority, a lesbian individual or group were faced with various issues, and one of them would be the threat of contracting HIV/AIDS.

Stevens (1994), states that AIDS increasing almost four times faster in the female group, but there are few studies that have been conducted to analyze this phenomenon on lesbian and bisexual women and the impact of AIDS epidemic on this popu- lation. Referring to the term lesbian, we must include their sexual activity as well as other activities that put them at the risk. Lesbian is often referred to women who have sexual interest to their own gender, but does it mean that they never have sexual relation with a man? to understand the context of risk on lesbian and WSW, we should understand the context of HIV among females. In which HIV directly connected with the act, not just the label that sticks on someone. Labelling an individual as a lesbian, gay, or even bisexual is not enough to describe the variety on their sexual relation. Some studies have proven that women who identify themselves as a lesbian but still have sex with a male, use drugs, being sex workers, an object of sexual violence and doing other risky activities that put them as a high-risk group to be infected by HIV (Scheer et al., 2002), but based on the data of HIV/AIDS patients, whether in global scale or nationnal, there is no specific case of HIV/AIDS in the lesbian community.

Rotheram-Borus et al. (1999) states that sexual identity does not necessarily explain the sexual activity. There is still an uncertainty on the definition of a "lesbian" that put the area and study focus into a haze. Furhermore, definition of "lesbian" could differ from each culture, race and ethnic groups. Dwarkin (2005) states that some women can identify themselves as a lesbian, but also involves in a sexual relation with males. On the other hand, some women, like Hispanic women in the survey for women with high risk in Los Angeles stated that they have sex with women but they are not lesbian.

There are a lot of women who believe that they are on "zero risks" in relation to HIV just because they only have sex with another woman. However, what is sex between two women? This is something that e-ISSN: 2549-1172 (online) 
the society or health professional could understand. CDC (2006) states that they have identified HIV virus to be transmitted through blood, menstrual blood, breast milk, and vaginal fluid. Therefore, the previous statement that women who have sex exclusively with women are on minimum or even zero risks of HIV, clearly abandoned the group that do the sexual activity by using the method of transmission. National AIDS Manual (NAM) has declares three sexual activities that often done by lesbian and bisexual women that include oral sex, sharing sex toy, and fisting/fingering (Cohen et al. 2004).

Furthermore, those three sexual activities actually put the lesbian and bisexual women in the high-risk group. From some sexual relation being mentioned, the informants admitted that they only wash their hands before and after any sexual activity and also use antiseptic. While the bisexual informant insisting her male partner to wear a condom, but there were a few times where she let him did not use protection while having sex. In terms of medical check-up, the informants admitted that they did not do medical check up regularly. As seen from their varied sexual activities, there were some things that would need more concern, especially any health issue that might occur.

First, all informants were under the risk of vaginal discharge problem. TrallopeKumar (2001) states that vaginal discharge (leukorrhea/fluor albus) as a condition on a vagina marked by having clear, thin liquid that do not smell or cause itch. This condition could be physiologycal or pathological. An abnormal discharge or pathological, the vagina fluid will be odorous, yellowish and cause itch. Zemouri et al. (2016) state that the abnormal discharge is caused by the bacteria, parasite or fungus in the vagina. One of the factors that can cause this would be using antiseptic that can change the vagina's $\mathrm{pH}$. Vaginal flora consisted of several bacteria, and one of them functions to protect the vagina and keep it in the normal range ( $\left.\mathrm{pH}_{3}, 8-4,5\right)$.

The result of the study stated that there is a misconception embedded in the informants on using antiseptic to keep their vaginas clean. This statement might be true to a point, but using too much of antibacterial can kill all the bacteria that would work to protect the vagina from any infection. Using the antiseptic too much could also contribute to causing pathological vaginal discharge. This state only worsened by the fact that the lesbian informants did not do a regular check up to know their status. They also admitted to not experiencing anything serious aside of foul odour vaginal discharge.

Second, there was a risk of vaginal infection as a bad effect from fingering or inserting bacteria-contaminated fingers into the vagina. The chance of HIV/AIDS to spread from fingering is often dismissed since it is considered of having very small chance to transmit HIV through this manner. Cohen et al (2004) state that fingering and fisting cannot transmit HIV/ AIDS as long as there is no open wound or bruise on the fingers. However, there was a case of HIV/AIDS transmitted through fisting and fingering happened to homosexual men in which one of them was diagnosed as a HIV positive. The sexual activity conducted was nothing more than kissing and fisting, but later they found that the gay couple was positive for HIV because of the open wound on a finger while doing fisting and fingering.

The chance for these activities to transmit HIV/AIDS is relatively low, but for the lesbian and bisexual women, the biggest threat they possess is the damaged mucous around the vagina that may cause an infect- 
Journal of Health Promotion and Behavior (2017), 2(1):15-26

https://doi.org/10.26911/thejhpb.2017.02.01.02

ion. This damage tissue will make them much more vulnerable to the infection happened from their next sexual activity. Even if the chance is considered as low, transmission through fisting and fingering should still be a concern.

Third, the threat of having sexually transmitted infection that happened through direct contact between mouth and genital. This is supported by the study conducted by Sandfort et al (2013), who state the high number of HPV and Bacterial Vaginosis (BV) on WSW in relation with the number of women's sexual partner. The incidence of HIV on WSW is related to their sexual activities with both gender and the use of injection drug. Richters (2008) states that in general, there are some STI that can happen through oral sex, whether fellatio or cunnilingus. Those STI are syphillis, gonorrhoea, herpes simplex, HIV, HPV, genital wart, Chlamydia, Hepatitis A, $\mathrm{B}$, and $\mathrm{C}$.

Moreover, D'Souza et al. (2014) state that one of the threats came from oral sex, especially cunnilingus, is the chance to have throat cancer. One of the viruses that can cause cancer is HPV (Human Papilloma Virus), as it is also one of the viruses that could spread STI like a genital wart or sometimes even symptomless. However, based on the report from US Center for Disease Control and Prevention (Chaturvedi et al, 2011), about $60 \%$ of oropharyngeal cancer (throat, tonsil and tongue cancer) was related to the HPV.

Furthermore, we analyzed the prevention behavior conducted by the informants by using the Health Belief Model. This model is the most commonly used theory to educate and promote health awareness. In the HBM concept, health behavior is influenced by personal belief or individual perception toward a disease, or in other words, Health Belief Model is a determi- nant model of health behavior (Rawlett, 2011).

The informants's personal perception related to susceptibility (perceived susceptibility) toward HIV/AIDS transmission. All informants who identified themselves as a lesbian did not see any susceptible to the infection because they perceived that the infection could only spread to those who have sexual relation with males. It means they had weak perception on Susceptibility toward HIV/AIDS. Those weak perception showed by no act for regularly medical check-up. On the other hand, informant who identified herself as a bisexual perceived herself as susceptible to the infection. Therefore, she took the necessary precaution by doing Pap smear regularly. It is in accordance with Maguen and Armistead (2000) who state the evidence on bisexual susceptibility in transmitting HIV/AIDS. In which the study result states that based on the identified sexual behavior, informants who have sex exclusively with women for entire life are at low risk for HIV, while bisexual informants are categorized as at high risk or highly susceptible to HIV. Having this perception, the lesbian informants do not do their regularly medical check-up.

Next, was the perceived severity. It is the individual assessment of the severity of diseases. One is likely to adopt a healthy lifestyle when knowing that they are on the risk for diseases (Tarkang and Francis, 2015). This perception appears when one considers that their current behavior would give a bad impact to their bodies in the future. When they perceive this as a severity, they will conduct a healthier lifestyle to minimize the chance from happening.

In terms of taking the precautionary behavior, lesbians who were involved in this study admitted that they did not do any medical check-up because they did not see 
any threat. On the contrary, the informant who identified as a bisexual stated that her current sexual behavior put her on the risk for HIV/AIDS and other STI. Therefore, she did Pap Smear regularly. This was supported by Gonzales et al. (1999) who state that women who have sexual relation with both men and women are on higher risk with various risky behavior. Therefore, the health workers must put concern on not only the lesbian but also bisexual women who are in the higher risk to get HIV or STI. Gonzales et al. (1999) also state that most bisexual women who suffer from AIDS in the United States are also injection drug users.

Both lesbian and bisexual who are in the sex trade also in the same risk to be HIV positive and this fact is worsened by the individual's perception that they do not possess any risk or have "zero risks" because they lack the knowledge and information about the risk factors. This leads to the individual to be unable to predict their future health condition.

The next discussion is related to perceived threat. Perceived threat emerges when an individual consider themselves to be vulnerable or at high risk to be infected, and see this as something serious (Tarkang and Francis, 2015). In this study, the informants especially lesbian ones did not do medical check-up regularly because they thought that HIV/AIDS is not a threat. This belief is something to be concerned about because the real threat happens when an individual feel healthy without doing the necessary medical check-up, as state in the study by Rotheram-Borus et al (1999), that WSW group is on the high risk for HIV infection when they believe that they are part of the low-risk group because of their sexual identity. Based on The Journal of the Gay and Lesbian Medical Association, there were $84 \%$ of 503 WSW informants who stated that they were on "zero risks" for HIV or other STI, despite the fact that these women were involved in other sexual activities including blood and other bodily fluid also involved in a sexual relation with men (Mercer et al, 2007).

The next aspect is the perceived benefit. It is an individual assessment related to personal behavior that can prevent or even lower their risk to certain disease. This perception plays an important role for an individual to adopt a healthy lifestyle (Tarkang and Francis, 2015). In term of medical check-up, researchers only found one informant who regularly did medical check-up, that was the informant who identified herself as a bisexual. Supporting the study by Maguen and Armistead (2000) who state that even though this group is at high risk of HIV/STI infection, only a few of the member who will do HIV test. This is the result of their lack of awareness of HIV status, especially in the lesbians group. The perceived benefit stresses on the drive to take an action as the result of positive result which is perceived. This perception is immeasurable within the context of the prevention behavior of HIV/AIDS for the lesbian, moreover on the medical check-up. This is caused by the absence of informant who conduct a regularly medical check-up, whether it is pap smear, IVA, or VCT test.

As for the perceived barrier, which is the individual perception on things that will be troublesome for them to adopt new behavior which is more healthy. From all of the Health Belief Model construct, the barrier an individual felt the most will be on deciding a change in their behavior (CDC, 2012). In this study, both lesbians and bisexual women possessed similar barrier which was on doing medical checkup. Particularly, feeling uncomfortable with the medical examiner, fear of their identity being exposed to the public, and did not 
Journal of Health Promotion and Behavior (2017), 2(1):15-26

https://doi.org/10.26911/thejhpb.2017.02.01.02

have enough time to access any health service. Up to this day, the lesbian women in Surakarta are not encouraged to be open and talk honestly about sex, whether it is to the same sex or the opposite. Another factor that makes it difficult to access the lesbian community is that they feel threatened that their identities would be known by many.

We also analyzed cues to action, in which referring to things that could affect someone to conduct healthy behavior. Cues to action can be an individual or groups, incidents, medias, and family members. In this study, the cue to action for the informants to conduct healthy behavior was their own selves. There was a drive within to stay healthy that pushed them to instill a precaution steps on preventing HIV/AIDS like washing their hands and using antiseptic before and after sexual activity as well as doing regularly medical check-up for the bisexual informant. However it did not apply lesbians in doing regular medical check-up because they believe that they were in the "zero risk" group and it was lead the lesbian informants not to visit any health care service regularly.

The self-efficacy on lesbian community is their own personal assessment on how well they are on implementing the healthy behavior (Rawlett, 2011). They did not understand the need for instilling a healthier habit since they still did not do the medical check-up regularly. However, there are some evidence of how lesbian was also at risk to be infected by HIV/AIDS or other STI. The lesbian and bisexual women were only considering the idea but did not take any step on properly do the necessary tests. This is caused by some psycho-social issues like fear of being left behind when being HIV positive in which this would limit their interpersonal relationship as well as with their surrounding.
Rotheram-Borus et al (1999) state some general reasons on why an individual refuses to take HIV test because it can induce stress, paranoia, and even suicidal tendency, as well as the lack of awareness of how important the test is. Based on the discussion above, we define a health act determinant model based on the identification of some informants (the lesbians in Talita Kum and Supporting Informants):

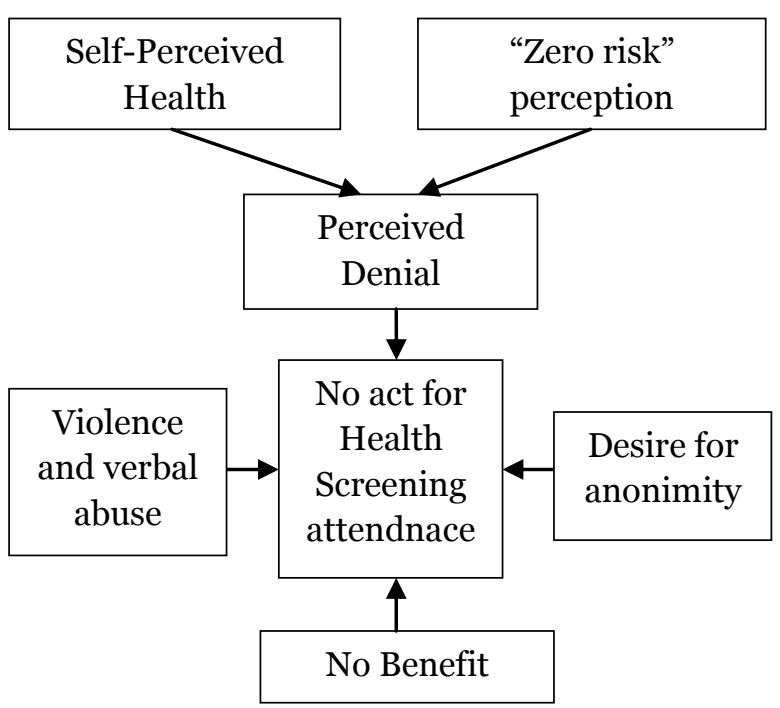

Picture 1. The determinants of HIV/AIDS prevention behavior on Talita Kum Lesbian

In addition we formulated Perceived Denial as a new finding to complete health belief model construct. Perceived Denial is an individual perception that emerges based on a strong self-belief of a zero risk on HIV/AIDS or other sexually transmitted infections. This is proofed in the absence of routine health checks by both individual or group initiatives. This perception also reinforces the reasons why lesbians are not involved in HIV/AIDS prevention programs such as IVA, Pap Smear or VCT. Health Belief Model explained that strong or positive beliefs can encourage a person to behave healthily. But in this study, selfbelief can lead to a perception of denial (perceived denial) resulting in the output of non-compliance or unwillingness to per- 
form regular health checks, especially in lesbian groups.

Considering the result of the study it is important to give an understanding for the lesbian through Non-government Organization that already cooperating with the community to encourage them to believe that doing necessary medical test could be beneficial for them. They will know their health status and they will feel better by knowing their current health condition.

\section{REFERENCE}

$\overline{\text { Centers for Disease Control and Prevention }}$ (2006). Centers for Disease Control and Prevention Revised recommenddations for HIV testing of adults, adolescents, and pregnant women in health-care settings. Morbidity and Mortality Weekly Report 55: 1-17

Centers for Disease Control and Prevention (2012). Behavioral Interventions fro STD/HIV Prevention. Retrieved from https://www.cdc.gov/std/training/std101/presentations-2012/behavioral-interventions.pdf

Chaturvedi AK, Engels EA, Pfeiffer RM, Hernandez BY, Xiao W, Kim E, Jiang B et al. (2011). Human Papillomavirus and Rising Oropharyngeal Cancer Incidence in the United States. Journal of Clinical Oncology 29 (32): 4294-4301.

Cohen CE, Giles A, Nelson M (2004). Sexual Trauma associated with fisting and recreational drugs. Journal of Sexual Transmitted Infection 80: 469-470.

Doty N, Willoughby B, Lindahl K, Malik N. (2010). Sexuality Related Social Support Among Lesbian, gay, and Bisexual Youth. Journal of Youth Adolescence 39 (10): 1134-1147.
D’Souza G, Kluz N, Wentz A, Youngfellow, RM, Griffioen A, Stammer E, Guo Y. et al. (2014). Oral Human Papillomavirus (HPV) Infection among Unvaccinated High-Risk Young Adults. Journal of Cancers 6: 1691-1704.

Diaz T, Vlahov D, Greenberg B, Cuevas Y, Garfein R (2001). Sexual orientation and HIV infection prevalence among young Latino injection drug users in Harlem. J Womens Health Gend Based Med 10 (4): 371-380.

Dwarkin SL (2005). Who is epidemiology fathomable in the HIV/AIDS epidemic? Gender, sexuality, and intersectionality in public health. Journal of Culture, Health \& Sexuality 7 (6): 615-623.

Gonzales V, Washienko KM, Krone MR, Chapman LI, Arrendondo EM, Huckeba HJ, dan Downer A (1999). Sexual and Drug-Use Risk Factors for HIN and STDs: A Comparison of Women With and Without Bisexual Experiences. American Journal of Public Health 89 (12): 1841.

Hilgert M, Hogarth J (2003). Household Financial Management: The Connection between Knowledge and Behavior. Retrieved from http://heinonline.org/HOL/LandingPage?ha ndle $=$ hein.journals $/$ fedred $89 \&$ div $=90$ \&id $=$ \&page $=$.

Kementerian Kesehatan RI (2014). Situasi dan Analisis HIV AIDS. Jakarta: Pusat Data dan Informasi kementerian Kesehatan Republik Indonesia

Komisi Penanggulangan AIDS (KPA) Propinsi Jawa tengah (2015). HIV \& AIDS. Retrieved from : http://birohumas.jatengprov.go.id/ppid/wp-content/ uploads /2016/01/BUKU-SAKUKPA-2015.pdf. 
Journal of Health Promotion and Behavior (2017), 2(1):15-26

https://doi.org/10.26911/thejhpb.2017.02.01.02

Komisi Penanggulangan AIDS (KPA) Kota Surakarta (2016). Data kasus HIV/ AIDS Surakarta. KPA: Surakarta.

Leech N, Onwuegbuzie (2007). An Array of Qualitative Data Analysis Tools: A Call for Data Analysis Triangulation. School Psychology Quarterly; 22 (4): 557-584.

Maguen S, Armistead L (2000). Prevalence of unprotected sex and HIV-antibody testing among gay, lesbian, and bisexual youth. The Journal of Sex Research 37 (2): 169-174.

Mercer C, Baley J. Johnson A, Erens B, Wellings K, Fenton K, Copas A (2007). Women who report having sex with women: British National probability data on prevalence, sexual behaviour, and health outcomes. American Journal of Public Health 97 (6): 1126.

Rawlett K (2011). Analytical Evaluation of the Health Belief Model and the Vulnerable Populations Conceptual Model Applied to a Medically Underserved, Rural Population. International Journal of Applied Science and Technology 1 (2): 15-21.

Richters J (2008). Oral Sex and Young People. National Centre in HIV Social Research: The University of New South Wales.

Rotheram-Borus MJ, Marelich WD, Srinivasan S (1999). HIV risk among homosexual, bisexual, and heterosexual male and female youths. Archives of Sexual Behavior 28 (2): 159.

Sandfort TG, Bauman LR, Matebeni Z, Reddy V, Southey-Swartz I (2013). Forced Sexual Experiences as Risk Factor for Self-Reported HIV Infection among Southern African lesbian and Bisexual Women. Plos One 8 (1).

Scheer S, Peterson I, Page-Shafer K, Delgado V, Gleghorn A, Ruiz J, Molitor F et al. (2002). Sexual dan Drug Use Behaviour Among Women Who Have Sex With Both Women and Men: Result of a Populations-Based Survey. American Journal of Public Health 92 (7) : 1110-1112.

Stevens PE (1994). HIV prevention education for lesbians and bisexual women: A cultural analysis of a community intervention. Journal of Social Science \& Medicine 39 (11): 15651578.

Tarkang E and Francis Z. (2015). Application of the Health Belief Model (HBM) in HIV Prevention: A Literature Review. Central African Journal of Public Health 1 (1): 1-8.

Trallope-Kumar K (2001). Cultural and biomedical meanings of the complaint of leukorrhea in South Asian women. Tropical Medicine and International Health 6 (4): 260-266.

UNAIDS (2016). Global AIDS Update 2016. Retrieved from : http://www.unaids. org/sites/default/files/media_asset/g lobal-AIDSupdate-2016_en.pdf.

Washington State Department of Health (WSDH) (2014). HIV Prevention Education: An HIV and AIDS Curriculum manual for Health Facility Employees. 2014 Revised Edition. Retrieved from http://www.doh.wa.gov/portals/1/Documents/Pubs/410-007KNOWCurriculum.pdf.

WHO (2016). The Global HIV/AIDS Epidemic. Global Health Observatory (GHO) data.

Zemouri C, Wi TE, Kiarie J, Seuc A, Mogasale V, Latif A, Broutet N. (2016). The Performance of the Vaginal Discharge Syndromic Management in Treating Vaginal and Cervical Infection: A Systematic Review and MetaAnalysis. PloS One 11 (10): 1-21.

e-ISSN: 2549-1172 (online) 